\title{
ANALISIS TINGKAT KEMAMPUAN PEMECAHAN MASALAH GETARAN HARMONIS MELALUI MODEL PEMBELAJARAN PERUBAHAN KONSEPTUAL
}

\author{
Siti Zaenab*, Muh. Makhrus, I Wayan Gunada \\ Program Studi Pendidikan Fisika, Universitas Mataram \\ *Email: zaenabalmadani@gmail.com
}

DOI: http://dx.doi.org/10.29303/jpft.v5i1.813

\begin{abstract}
The study aims to analyze the problem-solving ability (PSA) of students during the learning process with conceptual change learning model. This research is included in quantitative descriptive research with three experimental classes. PSA at the time of learning is measured by an assessment instrument that refers to the problems in the LKPD and PSA evaluation sheet which contains two description questions at every meeting for four meetings. The assessment instrument refers to four PSA indicators, namely the ability to understand problems, plan solutions, carry out problem-solving, and check again, which is done during the learning process. Data analysis of PSA research results based on LKPD found that 58\% of students have PSA in the very good category and $42 \%$ in the good category, while based on the evaluation results at each meeting it was found that $27 \%$ in the very good category, $62 \%$ in the good category, and $11 \%$ in the medium category. Analysis of research data shows that the conceptual change learning model is good to improve the problem-solving ability of harmonic motion of students of SMAN 8 Mataram.
\end{abstract}

Keywords: Conceptual Change, Problem Solving Ability

\section{PENDAHULUAN}

Fisika merupakan bagian dari Ilmu Pengetahuan Alam (IPA). IPA tidak hanya terdiri dari kumpulan yang terisolasi satu dengan lainnya melainkan kumpulan ilmu pengetahuan yang terorganisasi secara sistematis. Walsh et al. (2007) menyatakan bahwa tujuan pembelajaran fisika tidak hanya menekankan pada perolehan hasil belajar, menghafal sejumlah fakta dan konsep, melainkan memiliki kemampuan pemecahan masalah fisika. Wena (2014) mengungkapkan bahwa idealnya aktivitas pembelajaran tidak hanya difokuskan pada upaya mendapatkan pengetahuan sebanyakbanyaknya, melainkan juga bagaimana menggunakan segenap pengetahuan yang didapat untuk menghadapi situasi baru atau memecahkan masalah-masalah khusus yang yang sedang dipelajari. Getaran harmonis merupakan salah satu materi fisika yang sering dianggap sulit oleh peserta didik (Husniyah et al. 2016). Hasil penelitian (Hariawan et al. 2013) menunjukkan bahwa meskipun peserta didik telah mengikuti pembelajaran dengan creative problem solving, namun peserta didik masih mengalami kesulitan dalam memahami dan menemukan solusi dari masalah yang diberikan.

Hasil observasi menunjukkan bahwa peserta didik masih mengalami kebingungan dan miskonsepsi setelah dilakukan pembelajaran fisika khususnya pada materi getaran harmonis, yaitu tentang hubungan antara massa, panjang tali dengan periode bandul dan sub materi pokok lainnya. Sebagian besar peserta didik kurang mengaitkan konsep yang telah dipelajari dalam getaran harmonis dengan masalah yang disajikan, sehingga peserta didik kurang mampu memecahkan permasalahan yang diberikan. Hasil observasi sesuai dengan yang diungkapkan oleh Adolphus et al. (2013) bahwa peserta didik sulit dalam mengidentifikasi parameter yang digunakan dalam menyelesaikan masalah getaran harmonis. Gunawan et al. (2018) menyatakan bahwa pada beberapa titik penyelesaian masalah, dimana siswa masih mengalami kesulitan maka bantuan dan 
pembiasaan penyelesaian masalah harus terus dilakukan.

Masalah ini disebabkan oleh pembelajaran di sekolah kurang memperhatikan konsepsi awal peserta didik, sehingga guru tidak mengetahui kebutuhan yang seharusnya dipenuhi dalam proses pembelajaran. Tuqalby et al. (2017) menyatakan hal yang sama bahwa guru kurang memperhatikan konsepsi awal peserta didik, sehingga beranggapan apa yang dipelajari tanpa ada arti karena tidak ada kaitannya dengan pembelajaran yang lalu maupun dengan peristiwa yang ada dalam kehidupan. Materi getaran harmonis yang seharusnya disajikan dengan melibatkan peserta didik secara langsung misalnya melalui praktikum (Huriawati et al. 2016). Pembelajaran dengan praktikum jarang dilakukan di sekolah yang menyebabkan peserta didik masih mengalami miskonsepsi dan kurang mampu memecahkan masalah setelah proses pembelajaran. Penilaian proses kurang diperhatikan oleh guru, yang diperhatikan hanya hasil akhir yang diperoleh peserta didik.

Salah satu alternatif pemecahan masalah pada pembelajaran fisika adalah penerapan model pembelajaran perubahan konseptual (MPPK). Denis et al. (2015) memandang perubahan konseptual sebagai seperangkat pengajaran yang digunakan untuk mengubah pandangan peserta didik yang dianggap masih belum sesuai dengan pandangan fisikawan hingga sesuai dengan pandangan fisikawan. Pembelajaran dengan MPPK memberikan kesempatan kepada peserta didik untuk mengungkapkan konsepsi awalnya kemudian secara langsung melibatkan peserta didik pada peristiwa nyata mengenai materi getaran harmonis yang sedang dibahas. Peserta didik mengalami proses kognitif ketika terlibat langsung sampai terjadinya perubahan konsep yang sesuai dengan konsep fisikawan menyebabkan peserta didik dalam menyelesaikan permasalahan fisika akan lebih mudah. Penggunaan MPPK merupakan salah satu cara untuk menutup gap diantara sains peserta didik dan sains para fisikawan (Makhrus, 2018). Permasalahan tersebut menarik perhatian peneliti untuk melakukan penelitian tentang analisis kemampuan pemecahan masalah (KPM) peserta didik di SMAN 8 Mataram dengan menerapkan MPPK pada proses pembelajarannya.

Model Pembelajaran Perubahan

Konseptual

MPPK merupakan salah satu model pembelajaran yang berlandaskan paham konstruktivisme (Eka et al. 2014). Teori konstruktivisme Piaget mengatakan ketika seseorang membangun ilmu pengetahuannya, maka untuk membentuk keseimbangan ilmu yang lebih tinggi diperlukan asimilasi, yaitu kemampuan pemecahan masalah yang efektif antara konsep lama dengan kenyataan baru (Makhrus et al. 2014). Teori konstruktivisme lainnya yaitu teori sosial Vygotsky berkeyakinan bahwa perkembangan yang baik tergantung pada faktor biologis dan faktor sosial sangat penting, di mana teori ini lebih menekankan pada aspek sosial dari pembelajaran (AlTabany, 2015). Penekanan pokok pada konstruktivis adalah situasi belajar, yang memandang belajar sebagai kontekstual (Hamdani, 2011). Peserta didik mengonstruksikan pengetahuannya sendiri, maka tidak mustahil dapat terjadi kesalahan dalam mengonstruksi, hasil konstruksi tersebut disebut dengan prakonsepsi (Suparno, 2013). Pembelajaran berdasarkan pandangan konstruktivisme sangat memperhatikan konsepsi awal dan peran peserta didik dalam pembelajaran, sehingga tercapai pembelajaran yang berpusat pada peserta didik (student center). 
MPPK berawal dari pandangan tentang perubahan konseptual akibat terjadinya proses kognitif. Posner et al. (1982) menyatakan bahwa perubahan konseptual terjadi melalui dua proses, yaitu asimilasi (proses penggabungan antara konsep baru dengan prakonsepsi peserta didik) dan akomodasi (konseptual struktur diakomodasi jika prakonsepsi bertentangan dengan konsep baru) (dalam Aydin, 2012). Perubahan konseptual dapat terjadi pada empat kondisi, yaitu ketidakpuasan dengan konsepsi awal, kejelasan, masuk akal, dan manfaat yang ada pada konsep baru (Kang et al. 2010). Kelemahan pada konsepsi awal dan kelebihan konsep baru menyebabkan terjadinya perubahan konseptual pada peserta didik menuju konsep yang benar.

Peserta didik sebelum memulai kegiatan pembelajaran fisika sudah memiliki berbagai macam prakonsepsi mengenai materi yang akan dibahas, baik itu bersifat abstrak maupun yang tidak dapat diamati langsung (Baser, 2006). Miskonsepsi yang dialami peserta didik banyak dipengaruhi oleh pengalaman atau kehidupan masa lalu yang menjadi penetahuan awal peserta didik (Ozkan \& Selcuk, 2012). Guru diharapkan menciptakan lingkungan belajar dengan melihat konsepsi awal peserta didik pada MPPK sebagai informasi untuk pembelajaran selanjutnya dan memperbaikinya dengan meyakinkan peserta didik pada konsep baru sesuai konsep fisikawan (Sarar et al. 2014). Langkah-langkah MPPK disajikan pada Gambar 1.

MPPK adalah model pembelajaran yang memperhatikan konsepsi awal peserta didik sehingga terjadi proses kognitif melalui kegiatan pembelajaran yang bermakna hingga ditemukan konsep baru yang sesuai dengan pandangan fisikawan.

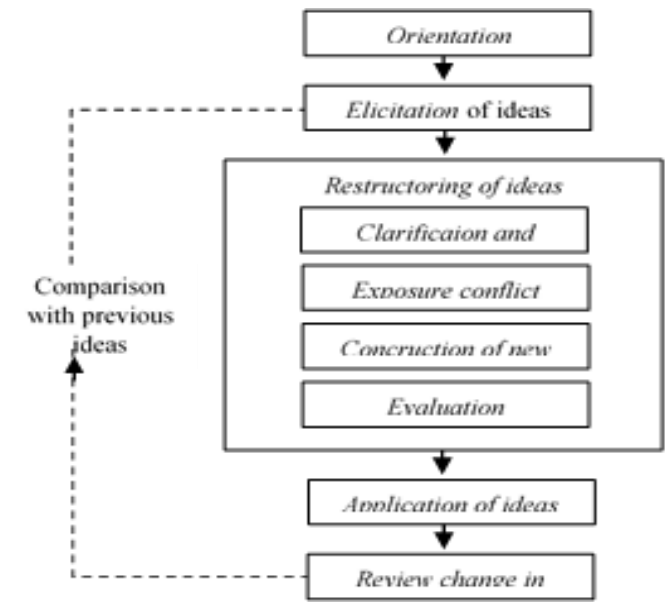

Gambar 1. Langkah-Langkah MPPK (Driver, 1988)

Manusia dalam kehidupan seharihari selalu dihadapkan dengan berbagai permasalahan. Masalah adalah suatu pernyataan atau informasi yang tidak sesuai dengan apa yang diharapkan dan apa yang seharusnya terjadi. Masalah akan menimbulkan kekacauan dan sesuatu yang membingungkan (Gunawan, 2017). Rusman (2016) menyatakan bahwa cara terbaik untuk mempersiapkan peserta didik di masa depan dengan dibekali strategistrategi pemecahan masalah yang mampu mengatasi tantangan-tantangan baru dan menemukan kebenaran-kebenaran yang relevan pada saat ini dan masa mendatang. KPM memerlukan suatu keterampilan dan kemampuan khusus yang dimiliki masingmasing peserta didik dalam meyelesaikan permasalahan dalam pembelajaran (Azizah et al. 2016). KPM pada penelitian ini diberikan penilaian berdasarkan empat indikator KPM yang dikemukakan oleh Selcuk et al. (2008), yaitu kemampuan memahami masalah, kemampuan merencanakan solusi, kemampuan melaksanakan penyelesaian, dan mengecek kembali. KPM adalah kemampuan dasar yang dimiliki peserta didik untuk menemukan solusi yang tepat dari permasalahan-permasalahan yang diberikan berkaitan dengan materi pembelajaran 
dengan menggunakan penalaran dan berpikir tingkat tinggi.

\section{METODE PENELITIAN}

Penelitian ini merupakan penelitian deskriptif kuantitatif karena kegiatan utama dalam penelitian ini yaitu mendeskripsikan tingkat KPM peserta didik. Desain pada penelitian ini yaitu one group pretest-postest dengan menggunakan tiga kelas eksperimen yang diberikan perlakuan dengan MPPK. KPM pada saat pembelajaran diukur dengan instrumen penilaian yang mengacu kepada permasalahan pada LKPD dan lembar evaluasi KPM berupa 2 soal uraian pada setiap pertemuan. Setiap pertemuan membahas masing-masing sub pokok materi getaran harmonis, yaitugaya pemulih, periode dan frekuensi, besaran-besaran fisis, dan energi mekanik pada getaran harmonis (empat kali pertemuan) berdasarkan indikator yang digunakan. Tingkat KPM dianalisis menggunakan statistik deskriptif. Klasifikasi KPM peserta didik dapat dilihat pada Tabel 1berikut.

Tabel 1. Klasifikasi Kemampuan Pemecahan Masalah

\begin{tabular}{ccc}
\hline Huruf & Nilai & Predikat \\
\hline A & $85-100$ & Sangat Baik (SB) \\
\hline B & $70-84$ & Baik (B) \\
\hline C & $55-69$ & Cukup (C) \\
\hline D & $40-54$ & Kurang (K) \\
\hline E & $0-39$ & Sangat Kurang (SK) \\
\hline & & (Vitasari et al. 2017)
\end{tabular}

\section{HASIL DAN PEMBAHASAN}

Penelitian ini bertujuan untuk menganalisis tingkat kemampuan pemecahan masalah yang dialami peserta didik SMAN 8 Mataram pada materi getaran harmonis dengan penerapan MPPK pada saat proses pembelajaran untuk setiap pertemuan. Hasil penelitian berdasarkan LKPD didapatkan bahwa 58\% peserta didik memiliki KPM dalam kategori sangat baik dan $42 \%$ dalam kategori baik, sedangkan berdasarkan hasil evaluasi didapatkan bahwa $27 \%$ dalam kategori sangat baik, $62 \%$ dalam kategori baik, dan $11 \%$ dalam kategori cukup.

Data kemampuan pemecahan masalah peserta didik pada ketiga kelas eksperimen berdasarkan LKPD disajikan pada Tabel 2 berikut.

Tabel 2.Nilai KPM Melalui LKPD Saat Proses Pembelajaran

\begin{tabular}{|c|c|c|c|c|c|c|c|}
\hline \multirow{2}{*}{ Kelas } & \multirow{2}{*}{$\begin{array}{l}\text { Per } \\
\text { Ke- }\end{array}$} & \multicolumn{4}{|c|}{ Tingkat KPM } & \multirow{2}{*}{$\begin{array}{l}\text { Rata- } \\
\text { rata }\end{array}$} & \multirow{2}{*}{$\begin{array}{l}\text { Kate } \\
\text { gori }\end{array}$} \\
\hline & & $\mathbf{A}$ & B & $\mathbf{C}$ & $\mathbf{D}$ & & \\
\hline Eks. & 1 & 87 & 82 & 90 & 76 & 85 & SB \\
\hline \multirow[t]{3}{*}{1} & 2 & 80 & 93 & 95 & 89 & 90 & SB \\
\hline & 3 & 88 & 85 & 96 & 73 & 88 & SB \\
\hline & 4 & 82 & 93 & 98 & 70 & 88 & SB \\
\hline Eks. & 1 & 87 & 86 & 80 & 76 & 81 & B \\
\hline \multirow[t]{3}{*}{2} & 2 & 86 & 76 & 97 & 74 & 86 & SB \\
\hline & 3 & 96 & 95 & 90 & 50 & 84 & B \\
\hline & 4 & 91 & 84 & 87 & 64 & 82 & B \\
\hline Eks. & 1 & 88 & 82 & 86 & 81 & 84 & B \\
\hline \multirow[t]{3}{*}{3} & 2 & 86 & 81 & 96 & 79 & 88 & SB \\
\hline & 3 & 90 & 95 & 96 & 45 & 84 & B \\
\hline & 4 & 92 & 85 & 90 & 67 & 84 & B \\
\hline
\end{tabular}

Keterangan:

A: Memahami Masalah;

B: Merencanakan Penyelesaian;

C: Melaksanakan Pemecahan Masalah;

D: Memeriksa kembali

Data kemampuan pemecahan masalah peserta didik pada ketiga kelas eksperimen berdasarkan LKPD juga disajikan pada Gambar 2 berikut.

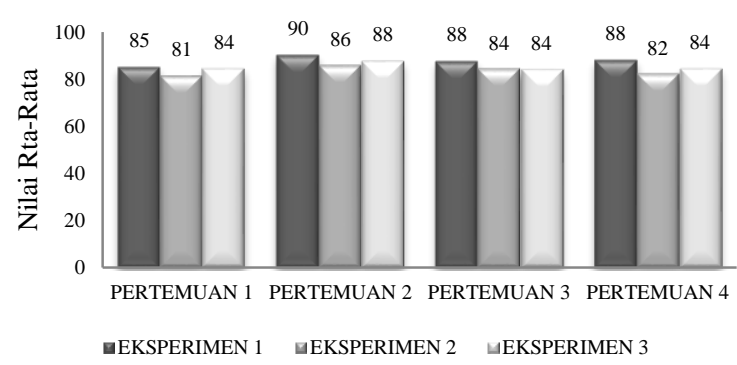

Gambar 2. Nilai KPM Melalui LKPD Saat Proses Pembelajaran

Data kemampuan pemecahan masalah peserta didik berdasarkan hasil evaluasi setiap pertemuan disajikan pada Tabel 3 berikut.

Tabel 3. Nilai KPM Hasil Evaluasi Saat Proses Pembelajaran

\begin{tabular}{cccccccc}
\hline \multirow{2}{*}{ Kelas } & Per & \multicolumn{4}{c}{ Tingkat KPM } & Rata- & Kate \\
\cline { 3 - 6 } & Ke- & A & B & C & D & rata & gori \\
\hline $\mathbf{1}$ & 79 & 82 & 77 & 44 & 72 & B
\end{tabular}




\begin{tabular}{cccccccc}
\hline \multirow{2}{*}{ Kelas } & Per & \multicolumn{4}{c}{ Tingkat KPM } & Rata- & Kate \\
\cline { 2 - 6 } Eks. & $\mathbf{2}$ & 68 & 75 & 95 & 70 & 80 & B \\
\cline { 2 - 6 } 1 & $\mathbf{3}$ & 83 & 75 & 94 & 75 & 84 & B \\
& $\mathbf{4}$ & 80 & 89 & 96 & 68 & 86 & SB \\
Eks. & $\mathbf{1}$ & 87 & 86 & 80 & 57 & 78 & $\mathrm{~B}$ \\
2 & $\mathbf{2}$ & 99 & 17 & 97 & 51 & 72 & $\mathrm{C}$ \\
& $\mathbf{3}$ & 91 & 89 & 56 & 51 & 69 & $\mathrm{C}$ \\
& $\mathbf{4}$ & 88 & 82 & 86 & 62 & 80 & $\mathrm{~B}$ \\
Eks. & $\mathbf{1}$ & 88 & 82 & 86 & 60 & 80 & $\mathrm{~B}$ \\
3 & $\mathbf{2}$ & 73 & 51 & 89 & 60 & 72 & $\mathrm{C}$ \\
& $\mathbf{3}$ & 86 & 85 & 88 & 45 & 78 & $\mathrm{C}$ \\
& $\mathbf{4}$ & 89 & 82 & 88 & 60 & 81 & $\mathrm{~B}$ \\
\hline
\end{tabular}

Data kemampuan pemecahan masalah peserta didik berdasarkan hasil evaluasi setiap pertemuan juga disajikan pada Gambar 3 berikut.

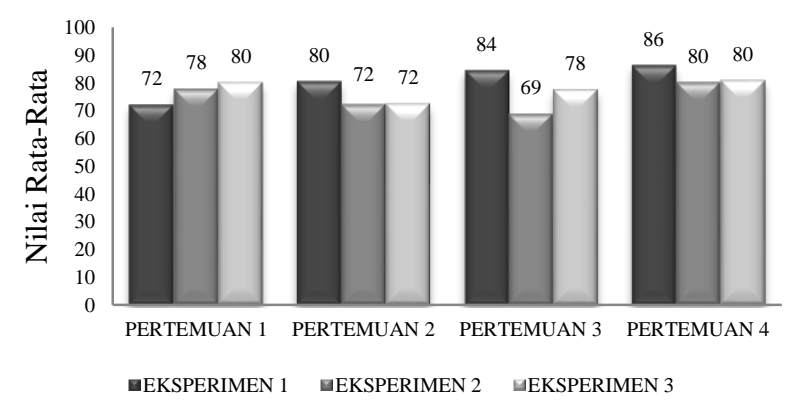

Gambar 3. Nilai KPM Hasil Evaluasi Saat Proses Pembalajaran

Tingkat KPM yang diukur berdasarkan empat indikator pemecahan msalah (IPM), yaitu kemampuan memahami masalah (skor 2), merencanakan solusi (skor 2), melaksanakan penyelesaian (skor 4), dan mengecek kembali (skor 2). Contoh penilaiannya pada soal no. 1 sub materi pokok gaya pemulih pertemuan 1 berdasarkan soal evaluasi. Peserta didik pada IPM-1 diharapkan mampu menuliskan besaran-besaran yang diketahui sekaligus besaran-besaran yang ditanyakan dalam soal getaran harmonis (menuliskan besaranbesaran diketahui, yaitu massa, simpangan, dan panjang tali, dan besaran yang ditanyakan, yaitu gaya pemulih). IPM-2, peserta didik diharapkan mampu menentukan dan menuliskan persamaan dengan tepat berdasarkan indikator yang pertama $\left(F=m g \frac{y}{l}\right)$. IPM-3, peserta didik diharapkan mampu menuliskan proses dalam menjawab soal berdasarkan indikator yang kedua (memasukkan nilai besaranbesaran pada persamaan IPM-2). IPM-4, peserta didik diharapkan mampu menuliskan satuan dan jawaban terakhir dari soal getaran harmonis (nilai $\mathrm{F}$ dan satuannya $\mathrm{N}$ ) dan begitu seterusnya untuk soal-soal yang lain. Penilaian dilaksanakan pada saat proses pembelajaran setiap pertemuan untuk empat kali pertemuan yang membahas empat sub materi pokok. Sub materi pokok dibahas empat kali pertemuan, yaitu, gaya pemulih, periode dan frekuensi, besaran-besaran fisis, dan energi mekanikkk pada getaran harmonis menggunakan LKPD dan lembar evaluasi pada akhir pembelajaran, karena penilaian proses lebih penting dari pada penilaian hasil untuk mencapai tujuan pembelajaran fisika melalui MPPK. Redhana et al. (2017) mengungkapkan hal yang sama, bahwa dalam pandangan konstruktivisme pemahaman pembelajaran lebih menekankan pada proses dari pada hasil untuk menciptakan pembelajaran yang aktif dengan menemukan sendiri pengetahuan dan pemahamn dari fakta pada pembelajaran.

MPPK yang diterapkan pada penelitian ini menunjukkan adanya latihan untuk membentuk KPM dari LKPD yang diberikan kepada peserta didik sesuai dengan IPM yang digunakan. Rata-rata tingkat KPM yang dialami peserta didik pada saat pembelajaran di setiap kelas eksperimen berdasarkan hasil LKPD dalam kategori sangat baik untuk kelas eksperimen 1 dan baik untuk kelas eksperimen 2 dan 3 . Hasil ini dapat diperoleh karena peserta didik dapat berdiskusi dengan anggota kelompoknya. Tingkat KPM tertinggi untuk ketiga kelas eksperimen terdapat pada sub materi pokok periode dan frekuensi getaran harmonis karena peserta didik sudah mengetahui IPM uyang sehaarusnya ditulis. Tingkat KPM terendah untuk ketiga kelas 
eksperimen terdapat pada sub materi pokok gaya pemulih pada getaran harmonis karena merupakan sub materi pertemuan pertama, peserta didik kurang teliti, belum terbiasa dan megetahui IPM yang seharusnya ditulis dalam menjawab soal. KPM peserta didik yang dilatih selama proses pembelajaran di dalam kelas tentunya berdampak secara langsung terhadap tes evaluasi KPM yang diberikan pada setiap akhir pertemuan, untuk membuktikan KPM fisika khususnya materi getaran harmonis secara individu. Pembelajaran dengan MPPK melatih KPM peserta didik dalam setiap langkah-langkah pembelajarannya dan melalui LKPD. Didukung oleh Penelitian Ibrahim et al. (2017) menyatakan model pembelajaran conceptual understanding procedures (CUPs) berbantuan LKPD berpengaruh terhadap kemampuan pemecahan masalah fisika peserta didik dimana model tersebut menyebabkan peningkatan kemampuan pemecahan masalah fisika peserta didik yang yang positif. Peserta didik yang sering melatihkan kemampuan pemecahan masalah akan memberikan penjelasan yang lebih baik dalam menjawab permasalahan isomorfik (Gadgil\& Nokes, 2009). Hasil tes KPM peserta didik pada evaluasi KPM di setiap akhir pembelajaran untuk ketiga kelas eksperimen menunjukkan bahwa peserta didik dapat menerapkan KPM yang dimiliki selama proses pembelajaran di dalam kelas dalam menjawab pertanyaan-pertanyaan konseptual maupun matematis pada evaluasi setiap pertemuan dalam katagori tinggi. Tingkat KPM tertinggi untuk ketiga kelas eksperimen terdapat pada sub materi pokok energi mekanikkk getaran harmonis, karena sub materi tersebut persamaannya tidak terlalu banyak dan merupakan sub materi terakhir di getaran harmonis di mana peserta didik sudah terlatih dalam menjawab soal dengan KPM yang dimiliki. Tingkat KPM selain sub materi energi mekanikkk getaran harmonis pada ketiga kelas eksperimen sama rata. Kelas eksperimen 1 memiliki rata-rata KPM yang lebih tinggi dibandingkan kelas eksperimen 2 dan 3.

Peserta didik dominan memiliki IPM 2 dan 3 yang lebih tinggi dibandingkan dengan IPM yang lain, karena peserta didik kurang teliti, malas, dan tidak menuliskan diketahui, ditanya, dan satuan dari jawaban akhir, peserta didik kebanyakan langsung menulis persamaan dan proses dalam menjawab soal terutama pada pertemuan pertama. Tingkat KPM peserta didik meningkat pada pertemuan berikutnya karena peserta didik sudah terlatih dalam menuliskan jawaban sesuai dengan IPM yang digunakan meskipun terdapat beberapa peserta didik yang belum memenuhi semua indikator KPM, karena kurang teliti dan tergesa-gesa dalam menjawab soal.

KPM yang dilatih melalui MPPK akan menyebabkan peserta didik mengalami perubahan konseptual. Perubahan konseptual ini dapat terjadi setelah peserta didik menyadari adanya ketidakcocokan pengetahuan awalnya dengan konsep ilmiah melalui proses pembelajaran dengan MPPK di mana peserta didik terlibat secara langsung pada saat melaksanakan percobaan sehingga dapat menemukan sendiri konsep fisikawan bahwa berbeda dengan konsepsi awal peserta didik. Hal ini didukung oleh penelitian yang dilakukan oleh Hastuti et al. (2016) juga menyatakan bahwa kemampuan penyelesaian masalah akan sangat membantu siswa dalam meningkatkan penguasaan konsepnya begitu pula sebaliknya Demonstrasi dilaksanakan pada awal pembelajaran untuk mengetahui konsepsi awal peserta didik (langkah 1: Orientasi) merupakan salah satu metode untuk menimbulkan rasa ingin tahu peserta didik dalam memahami masalah pada materi yang akan dibahas. Rasa ingin tahu inilah yang akan merangsang ide-ide cemerlang dalam proses pemecahan masalah, sehingga semakin baik rangsangan untuk 
menimbulkan rasa ingin tahu maka peluang peningkatan kemampuan penyelesaian masalah semakin tinggi(Venisari et al. 2015).

Peserta didik memiliki pemikiran dan keyakinan yang berbeda tentang konsepkonsep fisika (Yumusak et al. 2015). Konsep-konsep fisika yang berbeda diperoleh dari kehidupan sehari-hari, pengalaman dan lingkungan belajar yang sering tidak sesuai dengan sifat sains (Ozkan \& Selcuk, 2015). Guru memberikan pertanyaan lanjutan mengenai miskonsepsi dari konsepsiawal (langkah 2: elisitasi gagasan) untuk menciptakan keraguan peserta didik terhadap konsepsi awalnya dan merencanakan solusinya. Rasa ingin tahu peserta didik untuk mencari konsep ilmiah akan membawa peserta didik pada upaya untuk melaksanakan solusi atas permasalahannya atau bahkan peserta didik akan menjadikannya penghubung antara konsepsi awalnya dengan konsep yang baru diterimasehingga terjadi proses kognitif (langkah 3: restrukturasi gagasan), dengan menjelaskan konsep sebenarnya dan melakukan percobaan untuk menemukan sendiri konsep fisikawan. Peserta didik akan lebih memahami konsep jika dilibatkan langsung pada saat proses pembelajaran. Fakta ini sesuai dengan pendapat Sarar et al. (2014) bahwa MPPK mendorong peserta didik untuk lebih bertanggung jawab atas pembelajaran mereka dibandingkan dengan kelas tanpa MPPK seperti terlibat dalam diskusi maupun memecahkan permasalahan. Makhrus et al. (2014) menyatakan bahwa MPPK akan menghubungkan peserta didik dalam pembelajaran aktif dengan tantangan yang disajikan pada awal pembelajaran. Tantangan tersebut berupa tugas peserta didik untuk membuat sebuah penalaran atas prediksi dan estimasi untuk menjelaskan strategi yang akan digunakan dalam menyelesaikan permasalahandengan pernyataan tertulis, gambar, atau model
fisika.Permasalahan disajikan juga pada LKPD untuk mengetahui KPM peserta didik secara berkelompok dan KPM peserta didik per sub materi secara individu diketahui melalui hasil evaluasi pada setiap pertemuan (langkah 4: aplikasi gagasan). Perubahan konsep peserta didik diketahui melalui kegiatan menanya kembali pertanyaanpertanyaan pada saat elisitasi gagasan untuk megecek kembali konsep yang dikuasai peserta didik (langkah 5: review perubahan gagasan).

Peserta didik ketika ditanyakan konsepsi awal, sebagian besar peserta didik mengalami miskonsepsi pada gaya pemulih dengan besarnya sama di setiap titik, padahal tergantung simpangan yang diberikan. Hubungan antara massa dengan periode dan frekuensi pada bandul, bahwa massa bandul mempengaruhi periode dan frekuensi, sedangkan secara ilmiah hanya dipengaruhi oleh panjang tali dan percepatan gravitasi bumi. Hubungan antara massa dan simpangan dengan periode dan frekuensi pada pegas, bahwa massa pegas tidak mempengaruhi dan simpangan mempengaruhi periode dan frekuensi, sedangkan secara ilmiah hanya dipengaruhi oleh massa dan konstanta pegas. Kecepatan pada getaran harmonis maksimum di titik tertinggi dan nol di titik kesetimbangan, secara teori sebaliknya maksimum di titik kesetimbangan. Energi mekanikkk di setiap titik berbeda, sedangkan secara teori sama di setiap titik. Peserta didik rata-rata mengalami perubahan konsep setelah pembelajaran melalui MPPK dengan KPM yang jauh lebih baik dibandingkan sebelumnya. MPPK memberikan pemahaman kepada peserta didik belajar dan menyediakan platform untuk studi masa depan dan pengetahuan yang efektif (Grimes, 2015).

Tingkat KPM di dalam proses pembelajaran di dalam kelas tentunya akan memberikan pengaruh pada hasil belajar 
peserta didik. MPPK merupakan model yang tepat untuk mengajarkan peserta didik dalam melatih KPM khususnya pada materi getaran harmonis, materi ini tidak hanya disampaikan dalam bentuk soal latihan melainkan diperlukan permasalahanpermasalahan yang bersifat kontekstual untuk membangun keaktifan peserta didik selama proses pembelajaran di dalam kelas yang disajikan di awal pembelajaran. Konsepsi awal perlu diperhatikan oleh guru karena setiap peserta didik memiliki pengetahuan dan pengalaman sebelum memasuki kelas.Peserta didik datang ke dalam kelas tidak dengan "kepala kosong", akan tetapi mereka sudah memiliki pengetahuan awal atau prakonsepsi yang berasal dari pengalamannya sendiri (Suparno, 2013). Konsepsi awal tersebut memberikan informasi kepada guru untuk melaksanakan pembelajaran yang sesuai dengan melibatkan lamgsung peserta didik pada saat pembelajaran sehingga tercipta pembelajaran yang bermakna. Cakir et al. (2002), setiap peserta didik memiliki struktur kognitif yang berbeda-beda karena kemampuan, latar belakang, sikap, dan pengalaman mereka yang berbeda, kemudian membangun pengetahuan baru mengenai struktur kognitif mereka sebelumnya.

Hasil KPM yang diperoleh dengan kategori tinggi, baik itu pada LKPD maupun pada saat evaluasi KPM di setiap akhir pertemuan menandakan bahwa MPPK baik diterapkan untuk meningkatkan KPM fisika khususnya materi getaran harmonis peserta didik SMAN 8 Mataram. Keberhasilan MPPK sesuai dengan yang dikemukakan Sarar et al. (2014) bahwa perbedaan KPM dan berpikir kritis peserta didik antara kelas yang menggunakan MPPK yang lebih baik dibandingkan dengan kelas tanpa MPPK. Makhrus (2018) menunjukkan bahwa MPPK dengan pendekatan konflik kognitif dapat membantu pebelajar dalam melakukan perubahan konseptual terhadap konsepsi fisika yang salah menjadi konsep yang sesuai dengan konsep fisikawan.

\section{PENUTUP}

KPM fisika peserta didik pada proses pembelajaran dikategorikansangat baik unruk kelas eksperimen 1dan baik pada kelas eksperimen 2 dan 3 berdasarkan LKPD sedangkan KPM dalam katagori baik pada ketiga kelas eksperimen berdasarkan hasil evaluasi pada setiap pertemuan melalui MPPK, sehingga melalui MPPK KPM fisika peserta didik dapat meningkat terutama pada materi getaran harmonis.

\section{REFERENSI}

Adolphus, T., Alamina, J., \& Aderonmu, T. 2013. The Effectsof Collaborative Learning on Problem SolvingAbilities among Senior Secondary School PhysicsStudents in Simple Harmonis Motion. Journal Education and Practice, 3(25),95100.

Al-Tabany, T. I. B. 2014. Mendesain Model Pembelajaran Terpadu Inovatif, Progresif, dan Kontekstual: Konsep, Landasan, dan Implementasinya pada Kurikulum 2013 (Kurikulum Tematik Integratif/TKI). Prenada Media Group: Jakarta.

Aydin, S. 2012. Remediation of Misconceptions about Geometric Optics Using Conceptual Change Texts. Journal of Education Research and Behavioral Sciences, 1(1), 001-012.

Azizah, R., Yuliati, Y., \& Latifah, E. 2016. Kemampuan Pemecahan Masalah Melalui Pembelajaran Interactive Demonstration Peserta didik Kelas X SMA pada Materi Kalor. Jurnal Pendidikan Fisika dan Teknologi, 2(2), 55-59.

Baser, M. 2006. Fostering Conceptual Change by Cognitive Conflict Based Instruction On Students' 
Understanding Of Heat and Temperature Concepts. Eurasia Journal of Mathematics, Science and Technology Education, 2(2), 96-114.

Cakir, O. S., Gebans, O., \& Yuruk, N. 2002. Effectiveness Conceptual Change Text-Oriented Instruction on Students Understanding Of Cellular Respiration Concepts. Biochemistry and Molecular Biology Education, 30, 239-243.

Denis, U. A. Williams, J. J., Dunnamah, A. Y., \& Tumba, D. P. 2015. Conceptual Change Theory as a Teaching Strategy in Environmental Education. European Scientific Journal, 11(35), 395-408.

Driver, R. $\quad 1988 . \quad$ Changing Conceptions.www.cdbeta.uu.nl/tdb/f ulltext/Tdbeta_6_2_Driver_1988.pdf , diakses tanggal 6 Januari 2018.

Eka, P. I. W., Sadia, I. W., \& Suastra, I. W. 2014. Pengaruh Model Pembelajaran Perubahan Konseptual terhadap Pemahaman Konsep Siswa Ditinjau dari Gaya Kognitif. E-Journal Program Pascasarjana Universitas Pendidikan Ganesha Program Studi IPA. 4, 1-12.

Gadgil, S.\& Nokes, T.J. 2009. Analogical Scaffolding in Collaborative Learning. Proceedings of Thirty first Annual Conference of the Cognitive Science Societ.

Grimes, M. W. 2015. How Does Learning in Leadership Work? A Conceptual Change Perspective. Journal of Leadership Education, 14(4), 16-45.

Gunawan, G., Suranti, N. M. Y., Nisrina, N., \& Herayanti, L. (2018). Students' Problem-Solving Skill in Physics Teaching with Virtual Labs. International Journal of Pedagogy and Teacher Education, 2, 79-90.

Gunawan. (2017). Keterampilan Berpikir dalam Pembelajaran Sains. Mataram: Arga Puji Press.
Hamdani. 2011. Strategi Belajar Mengajar. CV Pustaka Setia: Bandung.

Hariawan, Kamaluddin, \&Wahyono, U. 2013. Pengaruh Model Pembelajaran Creative ProblemSolving terhadap Kemampuan Memecahkan Masalah Fisika pada Siswa Kelas XI SMA Negeri 4 Palu. JurnalPendidikan Fisika Tadulako, 1(2), 48-54.

Hastuti, A., Sahidu, H., \& Gunawan, G. (2017). Pengaruh Model PBL Berbantuan Media Virtual Tehadap Kemampuan Pemecahan Masalah Fisika. Jurnal Pendidikan Fisika dan Teknologi, 2(3), 129-135.

Huriawati, F., Handhika, J., \& Luthfiaturrohmah. 2016. "Penerapan Media praktikum Gerak Harmonik Sederhana Menggunakan Osilator Digital Detector untuk Meningkatkan Hasil Belajar dan Keterampilan Proses Mahasiswa", dalam Seminar Nasional Fisika dan Aplikasinya, Madiun: Pendidikan Fisika IKIP PGRI.

Husniyah, A., Yuliati, L., \& Mufti, N. 2016. Pengaruh Permasalahan Isomorfik Terhadap Keterampilan Pemecahan Masalah Materi Gerak Harmonis SederhanaSiswa. Jurnal Pendidikan Sains, 4(1), 36-44.

Ibrahim, I., Kosim, K., \& Gunawan, G. (2017). Pengaruh Model Pembelajaran Conceptual Understanding Procedures (CUPs) Berbantuan LKPD terhadap Kemampuan Pemecahan Masalah Fisika. Jurnal Pendidikan Fisika dan Teknologi, 3(1), 14-23.

Kang, H., Scharmann, L. C., Kang, S., \& Noh, T. Cogninitive Conflict and Situational Interest as Factors Influencing Conceptual Changes. International Journal of Environmental \& Science Education, 5(4), $383-405$.

Makhrus, M. 2018. Validitas Model Pembelajaran Conceptual Change Model with Cognitive Conflict 
Approach. Jurnal Ilmiah Profesi Pendidikan, 3(1), 62-66.

Makhrus, M., Nur, M., \& Widodo, W. 2014. Model Perubahan Konseptual dengan Pendekatan Konflik kognitif (MPK-PKK). Jurnal Pijar. 9(1): 2025.

Ozkan, G. \& Selcuk, G. S. 2012. How Effective Is "Conceptual Change Approach" In Teaching Physics?. Journal of Educational And Instructional Studies In The World, 2(2), 182-190.

Ozkan, G. \& Selcuk, G. S. 2015. Effect of Technology Enhanced Conceptual Change Texts on Students' Understanding of Buoyant Force. Universal Journal of Educational Research 3(12): 981-988.

Redhana, I. W., Sudria, I. B. N., Hidayat, I., \& Merta, L. M. 2017. Identification of Chemistry Learning Problems Viewed from Conceptual Change Model. Jurnal Pendidikan IPA Indonesia, 6(2), 356-364.

Rusman. $2016 . \quad$ Model-Model Pembelajaran: Mengembangkan Profesionalisme Guru Edisi Kedua. Jakarta: PT Raja Grafindo Persada.

Sarar, M. M. A. 2014. The Effect of Using Stepan's Model of Conceptual Change on The Modification of Alternative Mathematical Concepts and The Ability of Solving Mathematical Problems of Ninth Grade Students in Jordan. European Scientific Journal, 10(22), 191-203.

Selcuk, G. S., Caliskan, S., \& Erol, M. 2008. The Effect Of Problem Solving Instruction on Physics Achiement, Problem Solving Performance and Strategiy Use. American Journal of Physics Education, 2(3), 151-165.

Suparno, P. 2013. Miskonsepsi Perubahan Konsep dalam Pendidikan Fisika. Jakaerta: Gramedia Widiasarana Indonesia.
Tuqalby, R., Sutrio, \& Gunawan. (2017). Pengaruh Strategi Konflik Kognitif Terhadap Penguasaan Konsep pada Materi Fluida Siswa SMAN 3 Mataram Tahun Ajaran 2016/2017. Jurnal Pendidikan Fisika dan Teknologi, 3(1), 8-13.

Venisari, R., Gunawan, G., \& Sutrio, S. (2017). Penerapan Metode Mind Mapping pada Model Direct Instruction untuk Meningkatkan Kemampuan Pemecahan Masalah Fisika Siswa SMPN 16 Mataram. Jurnal Pendidikan Fisika dan Teknologi, 1(3), 193-199.

Vitasari, N. \& Trisniawati. 2017. Peningkatan Kemampuan Pemecahan Masalah Matematis Mahasiswa PGSD Universitas Sarjana Wiyata Taman Siswa Melalui Problem Posing. Jurnal Taman Cendekia, 1(2), 78-86.

Walsh, I. N., Howard, R. G., \& Bowe, B. 2007. Phenomenography Study of Students' Problem Solving Approaches in Physic. Physical Review Special Topics-Physic Education Research, (Online,3, 020108).

Wena, M. 2014. Strategi Pembelajaran Inovatif Kontemporer. Jakarta Timur: PT Bumi Aksara.

Yumusak, A., Maras, I., \& Sahin, M. 2015. Effects of Computer-Assisted Instruction with Conceptual Change Texts on Removing the Misconceptions of Radioactivity. Journal for the Education of Gifted Young Scientists, 3(2),23-50. 